Columbia Law School

Scholarship Archive

2008

\title{
Accountability and Competition in Securities Class Actions: Why "Exit" Works Better than "Voice"
}

John C. Coffee Jr.

Columbia Law School, jcoffee@law.columbia.edu

Follow this and additional works at: https://scholarship.law.columbia.edu/faculty_scholarship

Part of the Securities Law Commons

\section{Recommended Citation}

John C. Coffee Jr., Accountability and Competition in Securities Class Actions: Why "Exit" Works Better than "Voice", 30 CARDOZo L. REV. 407 (2008).

Available at: https://scholarship.law.columbia.edu/faculty_scholarship/1527

This Article is brought to you for free and open access by the Faculty Publications at Scholarship Archive. It has been accepted for inclusion in Faculty Scholarship by an authorized administrator of Scholarship Archive. For more information, please contact scholarshiparchive@law.columbia.edu, rwitt@law.columbia.edu. 


\title{
ACCOUNTABILITY AND COMPETITION IN SECURITIES CLASS ACTIONS: WHY "EXIT" WORKS BETTER THAN "VOICE"
}

\author{
John C. Coffee, Jr. ${ }^{*}$
}

\author{
INTRODUCTION
}

A sizable literature on class actions has long suggested that the plaintiff's attorney is an independent entrepreneur over whom the class members have only limited control. ${ }^{1}$ But the analysis cannot stop here. Why does this state of affairs exist? This essay will give two connected answers to this question as a prelude to evaluating what reforms are likely to work:

(1) The rules of "litigation governance" differ diametrically from those of corporate governance. An entrepreneur seeking capital for a business venture must convince investors to "opt in" and buy the securities of the entrepreneur's start-up corporation. In contrast, a plaintiff's attorney can file a class action which, if successful, will entitle this legal entrepreneur to a mandatory court-awarded fee, and class members can escape inclusion only by "opting out."2 This stark difference between an "opt in" rule for corporate governance and an

* John C. Coffee, Jr. is the Adolf A. Berle Professor of Law at Columbia University Law School and Director of its Center on Corporate Governance.

1 See, e.g., John C. Coffee, Jr., Understanding the Plaintiff's Attorney: The Implications of Economic Theory for Private Enforcement of Law Through Class and Derivative Actions, 86 COLUM. L. REV. 669 (1986); Jonathan R. Macey \& Geoffrey P. Miller, The Plaintiffs' Attorney's Role in Class Action and Derivative Litigation: Economic Analysis and Recommendations for Reform, 58 U. CHI. L. REV. 1 (1991).

2 Actually, there is only a right to "opt out"-that is, exit the class-in the case of class actions certified under Rule 23(b)(3). See Fed. R. Civ. P. 23(c)(2)(B). If an action is instead certified under Rule 23(b)(1) or (b)(2), Rule 23 does not mandate a right to opt out. But see Molski v. Gleich, 318 F.3d 937, 948-49 (9th Cir. 2003) (holding that the right to opt out may be constitutionally required when class members have substantial monetary claims); Beckert $\mathrm{v}$. TPLC Holdings, Inc., 221 F.3d 870, 873-74, 881-82 (7th Cir. 2000). The Supreme Court has not yet decided whether the right to opt out from a class action for money damages is of constitutional stature. For a review of recent decisions, see Rima N. Daniels, Monetary Damages in Mandatory Classes: When Should Opt-Out Rights Be Allowed, 57 ALA. L. REV. 499 (2005). Because most class actions for money damages are certified under Rule 23(b)(3), this limitation on the right to opt out in the case of Rule 23(b)(1) and (b)(2) classes has only modest implications and will receive no further attention herein. 
"opt out" rule for litigation governance explains, at least in part, why agency costs are higher in the latter context.

(2) The market for class action counsel has long been characterized by relatively weak competition. To be sure, some competition exists, but, as explained later, it is today fought, not for the loyalty of class members, but rather over the choice of the lead plaintiff.

Brief and incomplete as these two assertions are, they frame important policy questions. Because the "opt out" rule for class actions gives plaintiff's attorneys much of their bargaining leverage in class actions, it is not easily modified or discarded. However, it also implies imperfect accountability and high agency costs because class members did not select their attorney, did not choose to sue, and were not necessarily even aware of the existence of the action. Thus, the usual vocabulary used to describe the attorney/client relationship fits only awkwardly with this joint venture in which the attorney represents a class that has not retained the attorney in return for a basically predictable share of the recovery that the court (and not the class) will award if the action settles. Still, what alternative is there? Can we design alternative institutional arrangements that will reduce the agency costs surrounding reliance on the attorney/entrepreneur who today dominates class action practice? This essay's answer is that by encouraging opt outs, public policy can stimulate greater competition and compel class attorneys to become more faithful champions.

This focus on competition is somewhat heretical. For some time, public policy has been guided by the implicit assumption that an allinclusive class was desirable (because it minimized repetitive litigation and so conserved judicial resources) and that greater accountability should be encouraged by giving dispersed class members a stronger voice in the governance of the class action. Thus, the "lead plaintiff" reform, introduced by the Private Securities Litigation Reform Act of 1995 ("PSLRA"), assigned presumptive control over the securities class action to the class member with the largest stake in the action. ${ }^{3}$ The premise here was that the investor with the largest stake in the action could best monitor the class' attorney. Although an original and cogent idea, ${ }^{4}$ this reform appears to have had only modest impact on settlement

3 Section $21 \mathrm{D}(\mathrm{a})(3)$ of the Securities Exchange Act of 1934, 15 U.S.C. $\S 78 \mathrm{u}-4$ (a)(3), creates a rebuttable presumption "that the most adequate plaintiff in any private action arising under this title is the person or group of persons that ... has the largest financial interest in the relief sought by the class ...." Effectively, this means that an institutional investor owning a significant number of shares purchased during the class period can take control of the action and select class counsel-without itself even filing a complaint. For an overview, see Lisa L. Casey, Reforming Securities Class Actions from the Bench: Judging Fiduciaries and Fiduciary Judging, 2003 B.Y.U. L. REV. 1239.

${ }^{4}$ Full credit must be given to Professors Elliott Weiss and John Beckerman for crafting this proposal. See Elliot J. Weiss \& John S. Beckerman, Let the Money Do the Monitoring: How Institutional Investors Can Reduce Agency Costs in Securities Class Actions, 104 YALE L.J. 2053 
size to date. ${ }^{5}$ Indeed, this essay will predict that similar efforts to give the class members a greater role in electing or appointing a class-wide champion will yield only similarly marginal and disappointing results.

If so, what measures might work better? Using a nomenclature first developed by the economist Albert O. Hirschman, ${ }^{6}$ this essay will argue that the fallacy in recent reforms has been their emphasis on increased "voice" for class members, instead of increasing their ability to exit the class. The "exit" option essentially relies less on a global agent for the class and encourages some class members to select their own agents. To be sure, others will be unable to afford private counsel and will be compelled to rely on class counsel. But to hold potential "opt outs" within the class, class counsel is motivated to do more (or charge less). That "exit" may work better than "voice" is evidenced by the striking disparity that has recently arisen between the modest payouts to class members who remain in the class versus the much higher returns to institutional investors who opt out and sue in individual actions. ${ }^{7}$ Ultimately, as "exit" becomes a more popular option, it should at last encourage real competition in the market for class action professional services-that is, unless it can be thwarted by adaptive responses by defendants and others, which possibility also looms.

But greater exit is not a panacea. Ironically, it could even make shareholders worse off under some scenarios. Two basic "downside" scenarios exist.

First, the gains to those class members who exit the class could come at the expense of the smaller shareholders who remain in the class. Because a smaller class implies a smaller recovery and thus a smaller fee award, class counsel's incentive could be diluted. At least in theory, the net result could be a zero-sum game in which larger shareholders win, but smaller shareholders lose.

Second, because recovery in securities class actions is ultimately funded by the shareholders themselves, higher recoveries could generate greater losses to investors. To understand this point, one must focus on the wealth transfers uniquely inherent in securities class actions. Typically, the members of the plaintiff class are paid the settlement by the corporation (and not by the individual defendants). As a result, the cost of the recovery falls primarily on those shareholders who are not in the class. Because most shareholders are diversified and, over time, will fall into both groups, even meritorious securities class actions may

(1995).

5 See infra notes 38-45 and accompanying text.

6 See Albert O. HiRschman, Exit, Voice AND Loyalty: Responses to DeCline in FIRMS, ORGANIZATIONS, AND STATES (1970).

7 See infra notes 50-70 and accompanying text. 
simply transfer wealth among diversified shareholders, thus producing neither net compensation nor real deterrence. ${ }^{8}$ Worse yet, on each such wealth transfer among shareholders, lawyers for both sides extract their fees, thus ensuring that shareholder wealth is diminished. To the extent that this critique is accurate, reforms that enhance the position of the shareholder plaintiff could make securities litigation even more costly to most shareholders by subjecting them to more wealth transfers. In this light, the paradoxical problem with greater accountability is that the interests of the shareholder plaintiffs and those of shareholders generally can diverge.

At the outset, this essay needs to emphasize that, although it voices serious criticisms of current class action practice, it also rejects some of the standard critiques of the class action. This essay shares little common ground with a viewpoint that much of the defense bar has endlessly reiterated: namely, that securities class actions are frivolous and extortionate, brought by legal shake-down artists seeking a quick payoff. ${ }^{9}$ No time will be spent evaluating this critique, because it is shrill, self-interested, and shallow-and also very out of date. As a result of the PSLRA, recent Supreme Court decisions, and recently tightened class certification standards, the truly "frivolous" securities class action is today relatively rare-possibly even a mythic creature of folklore, like the unicorn, in that it is much discussed, but seldom objectively observed.

Organizationally, this essay will proceed in several stages. Part I will survey the conflicts that may exist between the class and its counsel

8 See John C. Coffee, Jr., Reforming the Securities Class Action: An Essay on Deterrence and Its Implementation, 106 COLUM. L. REV. 1534, 1556-66 (2006). For example, assume that a diversified public pension fund owns stock in 1,000 corporations and over a multi-year period, 100 of these corporations are sued in securities class actions. In 50 of these 100 cases, the pension fund purchased stock within the class period; in 50, it did not. All cases settle. As a result, at the end of this period, the pension fund has received the recovery in 50 cases and borne the recovery in the other 50. Moreover, on each wealth transfer, substantial deductions must be made for the legal expenses on both sides of the case and other transaction costs. These costs likely exceed $50 \%$ of the recovery, thus implying that securities litigation produces a net loss for our hypothetical pension fund. This same outcome follows in the equally likely case where the pension fund bought stock both before and after the start of the class period and thus effectively pays itself. To be sure, there may well be significant deterrent benefits from securities litigation, but that topic is also debatable and beyond the scope of this essay. See id. at 1547-51. For similar assessments, see Donald C. Langevoort, Capping Damages In Open-Market Securities Fraud, 38 ARIz. L. REV. 639 (1996); Jennifer H. Arlen \& William J. Carney, Vicarious Liability for Fraud on Securities Markets: Theories and Evidence, U. ILL. L. REV. 691, 698-700 (1992).

9 The traditional theory of the "strike suit" was that it was a non-meritorious suit that defendants found cheaper to settle for a small sum than to litigate. The settlement was thus based on a litigation cost differential that favored the plaintiffs, but recent studies suggest that smaller settlements are more a product of the issuer's size and the length of the class period than of the action's limited merit. For a critique of this "strike suit" theory, see James D. Cox and Randall S. Thomas, There Are Plaintiffs and . . There Are Plaintiffs: An Empirical Analysis of Securities Class Action Settlements 61 VAND. L. REV. (forthcoming 2008), available at http://ssrn.com/abstract $=1028287$. 
and make the case that enhanced exit and greater competition could alleviate some of these problems. Part II will examine the impact of "voice-based" reforms, most notably the "lead plaintiff" provision of the PSLRA. Part III will then turn to the "exit" option. Initially, it will describe the recent trend towards "opting out" by large investors in securities class actions and survey the differential in recoveries. Then, it will analyze the various reasons why "opt outs" appear to outperform class members in terms of their per share recoveries. Part IV will then examine the implications of these developments, considering such issues as (1) the impact of opting out on the remaining class members and on shareholders generally; (2) the tactics that defense counsel predictably may employ to deter opt outs; and (3) the implications under the Employee Retirement Income Security Act ("ERISA") for institutions who continue to serve as a lead plaintiff (specifically, does ERISA's "exclusive benefit" rule or similar common law obligations require a large institution to opt out?). Part V will then offer some tentative conclusions.

\section{THE ATTORNEY As ENTREPRENEUR: CONFLiCTS AND THE CASE FOR COMPETITION}

This essay will begin where a considerable body of academic scholarship (including by this author) has left off: namely, with the recognition that the plaintiff's attorney in class action litigation has broad and unconfined discretion. ${ }^{10}$ Obviously, such discretion implies a potential for opportunistic conduct by the attorney, but the deeper point is that this discretion arises because, and to the extent that, no meaningful principal/agent relationship exists between the plaintiff's counsel and its clients. As a consequence, the plaintiff's attorney can behave less as an agent serving a principal and more as an independent entrepreneur, one who in fact often hired the client. When the attorney is able to hire the client, the normal principal/agent relationship has been reversed.

Once, this was only a dry, academic point, but recently it has grabbed headlines with the resolution of the Milberg Weiss case and the conviction of four of its former senior partners. ${ }^{11}$ Dramatic, juicy and

10 For earlier efforts by this author, see John C. Coffee, Jr., Class Action Accountability: Reconciling Exit, Voice, and Loyalty in Representative Litigation, 100 COLUM. L. REV. 370 (2000); John C. Coffee, Jr., The Regulation of Entrepreneurial Litigation, Balancing Fairness and Efficiency in the Large Class Action, 54 U. CHI. L. REV. 877 (1987); Coffee, supra note 1.

11 For overviews of this prosecution, see Martin Zimmerman \& Molly Selvin, Lawyer Cuts Deal in Kickback Case; Melvyn Weiss Was Accused of Paying Class-Action Plaintiffs. He Is Expected to Get 18-33 Months, L.A. TIMES, Mar. 21, 2008, at C3; Jonathan D. Glater, High Profile Lawyer Agrees to Guilty Plea, N.Y. TimES, Mar. 21, 2008, at C1. The law firm, now 
even scandalous as the Milberg Weiss prosecution may have been, what does it really prove? If it implied only that some professionals had cheated, this would not be surprising. Attorney misconduct happens on the defense side as well, as evidenced by recent revelations involving the role of attorneys in backdated stock options and accounting irregularities. Although the Milberg Weiss prosecution has revealed little behavior that was not already widely surmised, ${ }^{12}$ it does clearly show that over several decades the best known plaintiff's law firm in the securities class action field long maintained and paid a stable of inhouse clients, each owning small investments in a large portfolio of stocks. This arrangement gave Milberg Weiss instant access to clients who could serve as plaintiffs when a new case arose, enabling them to file their action before rival plaintiffs' firms might. Rather than serving as agent for its clients, Milberg Weiss simply in-housed the client to avoid delay and competition.

Some may still ask: But what is the real economic harm in the attorney hiring the client? After all, an apologist might plausibly argue that the interests of class members and their counsel are well-aligned because the plaintiff's attorney is generally paid a percentage of the recovery and thus has an obvious incentive to maximize the size of the recovery - thereby benefiting its clients. ${ }^{13}$ Why, then, is client control so important? The answer here is critical: Absent client control, the plaintiff's attorney will predictably deviate from the clients' preferences to pursue the attorney's own interests. Why? The short answer is that when the plaintiff's law firm is able to act as a rational and unconstrained entrepreneur, it has very different interests, risk preferences, and incentives than those of its clients, the class members, and conflicts become inevitable. In the simplest and most extreme case,

known simply as "Milberg," has agreed to pay a $\$ 75$ million fine and accept certain other probationary convictions in order to avoid a criminal trial. See Jonathan D. Glater, Big Penalty Set for Law Firm, But Not a Trial, N.Y. TIMES, June 17, 2008, at A1.

12 In 1991, well before the current scandals, Professors Jonathan Macey and Geoffrey Miller wrote: "[A]ttorneys are routinely forced to circumvent ethical restrictions on solicitation and maintenance in order to obtain named plaintiffs as their ticket into profitable litigation." See Macey \& Miller, supra note 1, at 6 . With the passage of the PSLRA in 1995, paying the client went from the status of an ethical violation to a criminal one. Section $21 \mathrm{D}(\mathrm{a})(2)(\mathrm{A})(\mathrm{vi})$ of the Securities Exchange Act of 1934,15 U.S.C. $\$ 78 u-4(a)(2)(A)(v i)$, added by the PSLRA, requires the plaintiff in a securities class action to certify at the outset of the litigation "that the plaintiff will not accept any payment for serving as a representative party on behalf of a class" other than its pro-rata share of the recovery. Similarly, Section 21D(a)(4), 15 U.S.C. $\$ 78 u-4(a)(4)$, further provides that "[t]he share of any final judgment or of any settlement that is awarded to a representative party serving on behalf of a class shall be equal, on a per share basis, to the portion of the final judgment or settlement awarded to all other members of the class."

13 This is essentially the argument advanced by Myriam Gilles and Gary Friedman that because the class action attorney receives an established percentage of the recovery, the attorney's interests are well aligned with those of the class. See Myriam Gilles and Gary B. Friedman, Exploding the Class Action Agency Costs Myth: The Social Utility of Entrepreneurial Litigation, 155 U. PA. L. REV. 103 (2006). 
the plaintiff's attorney might exchange a cheap (or below-market) settlement for a lucrative (and above-market) attorney's fee paid in some form by the defendant. Class action law has long imposed some constraints designed to prevent such collusion: a requirement of judicial approval of any class action settlement, judicial control over fee awards, and, more recently, the "lead plaintiff" provision, which gives control of the class action to the class member with the largest stake in the action. But all have had only marginal success at best.

Even when actual collusion between the plaintiff's attorney and the defendants is not a factor, the more general problem is that plaintiff's law firm has multiple reasons to be far more risk averse than its class members and to settle more cheaply than its clients would want. First, plaintiff's attorneys have more at stake than their clients. Typically, class counsel expects a contingent fee in the vicinity of $25 \%$ of the recovery, ${ }^{14}$ and no class member will likely own a similar percentage of the defendant's stock to give it an equivalent stake in the action. Also, class counsel may often be required to invest millions of dollars in costs and expenses in order to advance the litigation. When one adds these two amounts - the expenses that the attorney must bear and the attorney's expected contingent fee-the attorney has far more at stake than any individual class member. Second, time is money, and delay for class counsel means additional costs and expenses that the attorney alone bears; thus, the attorney/entrepreneur has more reason to desire an early settlement than the client. This may lead the attorney to accept a large discount off the likely outcome at trial to obtain that settlement. ${ }^{15}$ Finally, because plaintiff's fee awards are typically a declining percentage of the recovery, ${ }^{16}$ the attorney benefits less from an increase in the recovery than does his or her clients. These factors can be

14 During earlier decades, the fee award in securities class actions averaged approximately $32 \%$ of the settlement. See Frederick C. DUNBAR, TODD S. FOSTER, VINITA M. JUNEJA \& Denise M. Martin, Recent TREndS III: What EXPlains SETtLEMENTS IN SHaReholder CLASS ACTIONS? 7 (June 1995); see also VINCENT E. O'BRIEN, A STUDY OF CLASS ACTION SECURITIES FRAUD CASES, 1988-1996, (also finding $32 \%$ to be the average fee award). The average fee award has probably declined in recent years, both because of the impact of the lead plaintiff and (at least as important) the advent of settlements near to or over $\$ 1$ billion. Because fee awards are a declining percentage of the recovery, higher settlements imply lower average fee awards (in percentage terms). Settlements over several hundred million dollars today often produce single digit percentage fee awards, but the $25 \%$ presumptive fee award remains alive and well in the case of lesser settlements. See Vizcaino v. Microsoft Corp., 290 F.3d 1043, 1052 (9th Cir. 2002) (appendix lists percentage of fund fee awards in cases where fund fell between $\$ 50$ and $\$ 200$ million between 1996 and 2001 and finds approximately half the fee awards were above $25 \%$ and half below); Craft v. County of San Bernardino, No. EDCV05-0359SGL, 2008 U.S. Dist. LEXIS 27526 at *39 (C.D. Cal. April 1,2008 ) (finding that " $25 \%$ is very much the norm").

15 Suggestively, some plaintiffs' attorneys are known-rather derisively in lawyer's vernacular-as "pilgrims" because they openly favor "early settlements."

16 See Theodore Eisenberg \& Geoffrey P. Miller, Attorneys Fees in Class Action Settlements: An Empirical Study, 1 J. EMPIRICAL STUD. 27 (2004). 
exploited by defendants, and they help explain why so few securities class actions ever go to trial. Risk aversion induces the plaintiff's attorney to settle at a discounted price that would not be attractive to a risk-neutral decision-maker, and crippling collective action problems prevent class members from objecting effectively.

Apart from these conflicts, class members may simply have heterogeneous preferences such that no single counsel can satisfy all of them. Some may wish to settle early, others to hold out; some want an all monetary recovery, while some public pension funds today desire corporate governance reforms to be incorporated into the settlement. These divergences provide an entirely alternative reason for opting out.

This thesis, that plaintiff's attorneys tend to be motivated to settle "cheaply" on terms that class members, if they had perfect knowledge and full control over their "agent," would reject, is corroborated by the extraordinarily low rate of recovery in securities class actions. According to one well-known study, the ratio of securities class action settlements to investors' economic losses has ranged over recent years between two and three percent. ${ }^{17}$ Of course, this low recovery rate could be explained by legal and factual difficulties inherent in the securities class action. Such difficulties do exist, and this interpretation would be plausible - but for new evidence, shortly to be discussed, that class members who opt out and flee the class seem to do extraordinarily better than those who remain within the class. Those who opt out face basically the same legal barriers; thus, if they do significantly better, the one variable that can most logically explain this difference in outcome is the different relationship that these "opt out" plaintiffs have with their attorneys. ${ }^{18}$

Even if class counsel in securities litigation has underperformed, is it reasonable to believe that class counsel's performance can be improved? As an opening generalization, whenever one detects slack or consistently substandard performance in a market (including a market for professional services), it is usually a safe diagnosis to predict that competition is lacking in the relevant market. As a result, the prescription may seem obvious; improve competition and presumably you will improve attorney performance. Yet, the PSLRA has done little to foster competition within the securities class action bar. ${ }^{19}$ Ironically, its principal impact has been to strengthen the incentives for firms to

17 In 2002, 2003, and 2004, the ratio was $2.7 \%, 2.9 \%$ and $2.4 \%$, respectively. The highest percentage that settlements have recently borne to investor losses was $7.2 \%$ in 1996 . See Elaine Buckberg et. al., RECENT TRENDS in SHAREHOlder Class ACTION LITIGATION: ARE WORLDCOM AND ENRON THE NEW STANDARD? 6 (NERA Econ. Consulting 2005).

18 See infra notes 71-75 and accompanying text. "Opt out" plaintiffs who sue in state court do escape the special barriers imposed by the PSLRA, but, as later discussed, this factor cannot alone account for the size of the disparity.

19 See infra notes 35-38 and accompanying text. 
cooperate, rather than compete. ${ }^{20}$ Also, as the PSLRA raised the level of risk associated with securities litigation while at the same time stretching out the period over which payment must be deferred to the contingent-fee compensated attorney, the PSLRA probably reduced the expected value of securities class litigation. In turn, this implied that only larger firms with diversified portfolios and better financing (or networks of firms, sharing the risk among them) could accept the enhanced risk and delay in securities litigation. Even though the PSLRA was aimed like a rifle shot at the Milberg Weiss firm, its initial impact was to strengthen the Milberg Weiss firm's oligopolistic position. $^{21}$

If enhancing competition should be the policy goal, how does one achieve this? To date, most policy proposals intended to hold plaintiff's counsel more accountable to the class have sought to give the class a greater "voice" in the selection and supervision of class counsel. The classic such reform is the PSLRA's "lead plaintiff" provision, which presumptively assigns control of the securities class action to the volunteering class member with the largest stake in the action. Such "voice"-based proposals may well be sensible, but they have done relatively little to improve competition. Rather, as discussed in more detail shortly, their practical effect has been to induce prospective candidates for class counsel to (a) join together to form the largest possible plaintiff consortium in order to win the lead plaintiff position, and (b) spend considerable sums soliciting and attracting large public pension funds, sometimes by questionable means. The wining, dining and political support of state pension officials-practices known in the parlance as "pay to play"-may be a form of competition, but it has done little for class members generally. Rather, such practices raise barriers that may exclude smaller and start-up firms that are either unable to make sizable political contributions or are too new to have already gained the good will of the officials that choose class counsel.

Less noticed than "voice," an alternative approach both makes more sense and has already begun to affect the competitive balance in the market for plaintiff's counsel. This alternative involves not enhanced voice, but greater use of right to exit the class-or "opt out" in the language of lawyers. To understand this approach, it is necessary

20 See infra notes 32-35 and accompanying text.

21 The Milberg firm did, however, move slower than its competitors to establish relationships with public pension funds, and this ultimately proved costly to them. For a time, they attempted to knit together large networks of individual plaintiffs to serve as lead plaintiffs, but the SEC opposed this effort as inconsistent with the intent of the PSLRA. See In re Baan Co. Sec. Litig., 186 F.R.D. 214 (D.D.C. 1999) (rejecting certification of class with 20 lead plaintiffs at SEC's urging). In an amicus brief, which the district court appended to its opinion, the SEC urged the Baan court to limit the lead plaintiffs to a "small number" so that they could feasibly monitor their counsel. 
to start with an insight first developed by Harvard economist Albert Hirschman, who noted decades ago in a slim and classic book that the real choice when one seeks to modify organizational behavior is between "voice" and "exit." 22 Hirschman postulated that the critical question was whether the members of the firm, organization or state would benefit more from (1) increased rights to participate in the body's governance, or (2) increased ability to flee the body at low cost. Ironically, while academics have largely missed the significance of this option and defendants have warned of the dangers associated with greater "exit" by class members, the reality is that the most sophisticated class members are today voting with their feet, fleeing the class and thereby expressing their preference of "exit" over "voice."

What specifically is happening? Since the modern class action rules were formalized with the promulgation of Fed. R. Civ. P. 23 in 1968 , class members in a class action seeking money damages (i.e., a Rule 23(b)(3) class action) have possessed an express right to "opt out" - that is, the right to exit the class and sue in an individual action. Recent federal decisions have treated this right as virtually an element of due process. ${ }^{23}$ Yet, over most of the interval between 1968 and today, this right has been generally viewed as illusory and largely worthless. Indeed, for most class members, the right to opt out probably is of limited value. This is because the basic rationale underlying the class action is that small claims only have value if they can be aggregated into a larger body that can afford the high transaction costs of litigation. ${ }^{24}$ Otherwise, small claimants hold "negative value" claims that cost more to enforce than they are individually worth. ${ }^{25}$ Given the prevalence of "negative value" claims in most class actions, the right to opt out represents merely a formal and empty right for most class members. But securities class actions are a marked and dramatic exception to this pattern. The rise of the institutional investor to the

22 HiRSCHMAN, supra note 6.

23 See Ortiz v. Fibreboard Corp., 527 U.S. 815 (1999) (instructing lower courts to avoid certifying non-opt out settlements except in strict compliance with Rule 23(b)(2)). Several subsequent decisions have rejected non-opt out settlements, citing constitutional concerns. Beckert v. TPLC Holdings, Inc., 221 F.3d 870, 873-74, 881-82 (7th Cir. 2000); Jefferson v. Ingersoll Int'l Inc., 195 F.3d 894 (7th Cir. 1999).

24 In Amchem Prods., Inc. v. Windsor, 521 U.S. 591, 617 (1997), the Supreme Court noted that the rationale for the class action lay in the fact that "small recoveries do not provide the incentive for any individual to prosecute his or her rights. A class action solves this problem by aggregating the relatively paltry potential recoveries into something worth someone's (usually an attorney's) labor."

25 Even those decisions most critical of the class action have recognized that "[t]he most compelling rationale for finding superiority in a class action [is] the existence of a negative value suit." See Castano v. Am. Tobacco Co., 84 F.3d 734, 748 (5th Cir. 1996). A negative value case is usually defined as a case "in which the costs of enforcement in an individual action would exceed the expected individual recovery." See In re Inter-Op Hip Prosthesis Lab. Litig., 204 F.R.D. 330, 348 (N.D. Ohio 2001). 
point where such investors today hold a majority of the stock in publicly-held firms (a development that was largely subsequent to the formalization of class action rules in 1968) ${ }^{26}$ implies that most of the stock purchased by the plaintiff class in a securities class action will be held by institutional investors whose large stakes can justify and support individual litigation. Indeed, because institutional investors tend to trade more actively than retail investors (who typically follow a buyand-hold strategy for a variety of reasons, including higher brokerage commissions), it follows that institutional investors will represent a higher percentage of the plaintiff class than they do of the shareholder population in general. Nevertheless, for a long time, institutional investors were indifferent to the prospect of litigation; indeed, they often failed even to claim their share of class action settlements. ${ }^{27}$ Only recently has this changed. Institutional investors have seen that large recoveries are possible in individual suits and are now prepared to sue. In response, a legal market has developed to solicit and accommodate them. This process is still ongoing and possibly at an early stage.

Now comes the next and even more surprising development: When institutional investors exit the class and sue individually, they appear to do dramatically better-by an order of magnitude! This development has generated anxiety among defendants and plaintiff's class counsel, both of whom will lose if class actions are depleted by a high percentage of opt outs. Ominous as this trend may appear to defense counsel, this essay's thesis will be that this is an optimistic development. It shows us a reform that actually works: liberalized "exit" can and does vastly outperform enhanced "voice." But what about the smaller retail shareholder who cannot opt out? How will they be affected? Although it is arguable that the smaller size of the remaining class (which implies a smaller fee award to plaintiff's counsel) will result in class counsel being less motivated, the alternative and more logical scenario is that increased "exit" will kickstart a more active competition into existence among plaintiff's attorneys. To prosper, each attorney must demonstrate that it can obtain superior results for its clients. If the class settlement seems "cheap," the larger institutions will simply flee the class by opting out. If one believes in competition, this is precisely how results should play out; that is, class

26 For general discussions of the level of institutional stock ownership and its shift over time, see John C. Coffee, Jr., Liquidity Versus Control: The Institutional Investor as Corporate Monitor, 91 COLUM. L. REV. 1277 (1991); Harold Demsetz \& Kenneth Lehn, The Structure of Corporate Ownership: Causes and Consequences, 93 J. POL. ECON. 1155 (1985).

27 See James D. Cox, Jr. \& Randall Thomas, Leaving Money On the Table: Do Institutional Investors Fail to File Claims in Securities Class Actions, 80 WASH. U. L.Q. 855 (2002); James D. Cox, Jr. \& Randall Thomas, Letting Billions Slip Through Your Fingers. Empirical Evidence and Legal Implications of the Failure of Financial Institutions to Participate in Securities Class Action Settlements, 58 STAN. L. REV. 411 (2005). 
counsel should be able to prosper if and only to the extent that the class is satisfied.

\section{Class Action Governance: Why Voice Does Not Encourage COMPETITION}

Prior to the PSLRA in 1995, securities class actions and antitrust class actions were organized in a basically similar fashion. Typically, a multiplicity of actions would be filed in district courts all over the country, and the Judicial Panel on Multidistrict Litigation ("JPML") would determine to which district court it would refer these actions for pre-trial coordination and discovery. ${ }^{28}$ Such a referral was necessary because otherwise the first plaintiff's team to settle with the defendants would bar the other suits, as the first settlement (and the release that the named plaintiff would grant incident to that settlement on behalf of the class) would carry preclusive effect. Today, this danger that the first team to settle wins has been largely mitigated by the JPML, which moves all the competing actions to the same court and thereby discourages races to settlement, but the danger still arises when overlapping class actions are pending in state and federal court.

Let's assume then that the JPML assigns the case to a specific district court judge. What happens next? The classic folklore was that the first to file would be named lead counsel (and thus have control over the settlement process). But no decision or no judicial rule ever articulated such a standard.

What actually happened was more complex. The court to which the JPML assigned the case might find that it had ten to twenty different complaints before it, each seeking discovery or pretrial relief. The logical first step for the court was to organize the action, establishing committees of counsel to deal with various issues. Recognizing that the court would eventually appoint a lead counsel, the participating law firms usually sought to preempt the court from choosing counsel by organizing their side of the case and electing their own lead counsel. Few courts were sufficiently strong-minded to reject the plaintiff's counsel's choice, particularly when this saved the court work. The result was usually a hotel room political convention at which all the participating plaintiff's attorneys elected a lead counsel and a steering committee. As in all political conventions, political horse trading

28 The JPML was created in 1968 (at roughly the same time as the modern class action rules were formalized). See Pub. L. 90-296, $\S 1,82$ Stat. 109 (1968) (codified at 28 U.S.C. $\S 1407$ ). The powers of the JPML were trimmed by the Supreme Court in Lexecon Inc. v. Milberg Weiss Bershad Hynes \& Lerach, 523 U.S. 26 (1998), which held that, after discovery was completed, the case had to be transferred back to the original court in which it was filed. 
occurred. In order to win votes, a candidate had to broker deals under which those supporting the candidate would be placed on the steering committee and effectively promised billable work for which they could earn fees (if the action settled). The losing side would receive no such promises and might be excluded from work assignments; thus, they might receive no fees, because the court awarding fees would usually defer to the allocation of fees within this ad hoc law firm recommended by the elected class counsel.

Sometimes, disputes would flair and the contending sides would appear before the judge and publicly criticize each other. In these disputes, the truth sometimes emerged that many attorneys in smaller law firms had been invited into the action not to litigate, but to vote for their friends. ${ }^{29}$ The core problem with this political convention approach to the organization of an "ad hoc" plaintiff"s law firm was that there was no nominating or credentials committee that decided who was eligible to vote. As a result, the ballot box could be stuffed. More typically, however, the action would get organized on an amicable basis (but one that recognized the political strength of the contending factions). Some plaintiff's attorneys were noted for their political skills at crafting compromises and fashioning acceptable slates. Although they were not necessarily excellent litigators, they would inevitably end up with some high position, either on the steering committee or as colead counsel, because they could broker deals.

What then explains the conventional "first to file, wins" perception? The "first to file" law firm often invited in its allies to ensure that it could outvote other potential contenders. Even those firms that were not such allies needed to file an action immediately to ensure that they would be included in the informal selection process. Once the potential candidates were known, the brokers could then strike deals, exchanging votes for their slate for critical seats on the steering committee. What looked from a distance like a competitive race was more a consensual and highly political process of log rolling.

A hidden cost was, however, associated with this system: overstaffing. Twenty attorneys or more might wind up with some position or title, but only some of them would do "real" litigation work. In turn, overstaffing forced productive attorneys to share their fees with unproductive (and indeed absent) attorneys, and this dulled the incentive of even the productive to work hard on the case. Because the fee award was inevitably limited by some maximum percentage of the recovery that the court would not exceed, ${ }^{30}$ participating counsel might

29 For a detailed examination of one such episode (involving an antitrust class action), see John C. Coffee, Jr., Rescuing the Private Attorney General: Why the Model of the Lawyer as Bounty Hunter is Not Working, 42 MD. L. REV. 215, 252-62 (1983).

30 During prior decades, this ceiling was somewhere above $33 \%$ of the action (which was the 
realize that all time expended on the case could not be successfully recovered. Thus, the "political" attorney who specialized in dealmaking within the plaintiff's team was effectively subsidized out of the pockets of those counsel who did the actual work.

Another consequence of this brokered system for the organization of the class action was that it eliminated open competition. Although there were occasional struggles within the plaintiff's camp that broke into the open, plaintiff's attorneys did not want these battles publicized. Most could not afford to make enemies within the plaintiff's bar for fear that they would be excluded from future plaintiff's teams. Smaller and new entrant firms learned, just like junior Congressmen, that one got along by going along. Overstaffed and undermotivated, the traditional "ad hoc" plaintiff's law firm was a model of inefficiency. ${ }^{31}$

The PSLRA changed this picture dramatically, but it did not increase competition. Being "first to file" no longer made any sense, because the PSLRA gave effective control of the securities class action to the class member or members with the largest losses who volunteered to serve, even if it never filed an action. Indeed, a large institutional investor could take control of the class action simply by offering to serve as lead plaintiff-without ever filing any lawsuit or seeking the support of others. Quickly, the plaintiff's bar learned to develop relationships with public pension funds, unions and other organizations that held large stock positions. Milberg Weiss moved relatively slowly towards this new system, hoping to continue to compete by assembling large aggregations of small plaintiffs. The SEC opposed such large aggregations, however, on the grounds that they could not adequately monitor the attorney and so were inconsistent with the PSLRA's statutory intent. ${ }^{32}$ As a result, because it changed its position slowly, Milberg Weiss's near monopoly position eroded, and other firms secured important lead counsel positions.

Although contests still arose under this system, the participants soon learned how to minimize them. Law firms could and did solicit institutions to serve as lead plaintiff (with the understanding that the law firm would be chosen by the institution as its class counsel), but other law firms could respond by seeking to assemble a rival and larger consortium of pension funds and thereby win the contest. Often, counsel feared up to the last moment that some rival firm or firms

average fee award in securities class actions). See supra note 14.

31 For discussions of patronage systems in which committee positions and leadership roles in the class action were awarded in return for support in the election of lead counsel, see Coffee, supra note 29 , at $256-58$.

32 The SEC expressed its opposition to a large number of shareholders sharing the position of lead plaintiff in In re Baan Co. Securities Litigation, 186 F.R.D. 214 (D.D.C. 1999). See supra note 20. Since that time, few law firms have attempted to assemble more than five or six shareholders to serve collectively as lead plaintiffs. 
would enter the competition with a larger consortium of clients. As a result, the logical strategy was not to proceed on a "lone wolf" basis, but instead to assemble groups of law firms who could combine their clients into a larger consortium of institutions. Put differently, it was in the interest of law firm X not to compete with law firm Y, but rather to pool their institutional clients so that they could stave off the threat from still other potential competitors.

Professors Choi and Thompson have provided empirical support for this hypothesis, finding that in the post-PSLRA period, the number of cases with a solo lead plaintiff law firm fell from $31.9 \%$ (in the prePSLRA period) to $19.6 \%$ immediately afterward..$^{33}$ Previously, consortiums of more than two law firms had been rare, but Choi and Thompson identified, out of a sample of 219 post-PSLRA suits, some 78 cases (or nearly $36 \%$ ) in which three, four, five or even more law firms shared the lead counsel position. ${ }^{34}$ Once again, the better political brokers could knit together large coalitions that would hold larger equity stakes.

In theory, law firms might share the lead counsel position for other reasons than the need to assemble the largest equity stake-for example, to create a synergistic combination of legal skills or to achieve efficient risk diversification. Although these could be secondary motives, the driving force in the real world was the need to protect one's position against potential larger coalitions that might arise at the last minute. Corroboration for this conclusion lies in the fact that, although law firms could always combine to serve as co-class counsel, sharing a single client, actual cases of co-counsel sharing a single client have proven rare, both before and after the PSLRA. This suggests that synergy and risk diversification were not the primary motivators behind law firm coalitions. Rather, the cement that held together law firm coalitions was the need to assemble a client mass that would preempt competitive efforts by other teams of attorneys. As noted above, only in $19.6 \%$ of the post-PSLRA cases did law firms proceed on a solo basis, and these cases probably consisted of either (1) those that were too small in terms of the expected recovery to attract competition or (2) those in which the solo firm represented a client of preemptive size (for example, CalPERS).

As experience was gained with contests over the lead plaintiff position, Choi and Thompson find that "repeat relationships" have developed "between lead plaintiff law firms and institutional investors" and that "institutional investors that potentially act as lead plaintiffs tend to develop repeat relationships with only a handful of the top-tier

33 See Stephen J. Choi \& Robert B. Thompson, Securities Litigation and Its Lawyers: Changes During the First Decade After the PSLRA, 106 COLUM. L. REV. 1489, 1520-21 (2006).

34 ld. at 1521 (Table 4). 
plaintiff law firms." 35 Choi and Thompson express uncertainty at what forces were behind these "repeat relationships," but certainly political campaign contributions were likely one such force (and competition on this score obviously favors the larger and entrenched law firm). To be sure, such "repeat relationships" could also be based on the institutions' successful prior experience with some law firms, but once these "relationships" formed, they became a barrier to new entrants.

At least in the case of the public pension funds, much anecdotal evidence suggests that inter-firm competition for class counsel is largely waged on a basis that does little for absent class members. Today, it is the common practice for the larger plaintiffs' firms to entertain the officials of public pension funds (often lavishly) and to make political contributions to the elected public officials who control the fund's decision. For example, in the case of New York State, the State Comptroller is the sole trustee with full power over their pension funds' respective decisions. As an elected official in a state characterized by notoriously expensive political campaigns, the New York State Comptroller needs to raise political contributions, and plaintiff's law firms need to curry his favor. Although this result was not intended by the PSLRA, it quickly became a marriage made in political heaven for both sides. To illustrate, in one major class action, the New York State Comptroller was estimated to have received $\$ 200,000$ in political contributions from two law firms (and the families of their partners) in the year following their selection as co-class counsel in a case in which the two firms eventually received a $\$ 55$ million fee award. ${ }^{36}$ In fairness, these contributions may often be defensive in character; that is, one plaintiff's law firm makes a contribution in order to keep pace with its rivals and not be excluded from consideration as class counsel. Nonetheless, the net result of this "pay to play" system of exchanging political contributions for lead plaintiff designations is to rent the pension fund as a lead plaintiff to the highest contributors. It may do little damage to the pension funds, but it does effectively exclude smaller firms and new entrants who have not previously made contributions.

Viewed in terms of a traditional antitrust concentration analysis, the overall concentration level within the securities plaintiffs' bar neither rose nor declined significantly after the enactment of the PSLRA in 1995. Professors Choi and Thompson estimate the market share percentage of the top five plaintiffs' firms before and after the PSLRA,

36 See James D. Cox \& Randall S. Thomas with Dana Kiku, Does the Plaintiff Matter? An Empirical Analysis of Lead Plaintiffs in Securities Class Actions, 106 COLUM. L. REV. 1587, 1611 (2006). 
as follows: ${ }^{37}$

\section{Pre-PSLRA Market Share Percentages}

Milberg Weiss

Wolf Haldenstein Adler Freeman \& Herz

Bernstein Litowitz Berger \& Grossmann

Berger \& Montague

Abbey \& Ellis/Abbey Gardy

Post-PSLRA Market Share Percentages

Milberg Weiss

$27.4 \%$

Bernstein Litowitz Berger \& Grossmann

$9.0 \%$

Wolf Popper

$5.7 \%$

Wolf Haldenstein Adler Freeman \& Herz

$5.4 \%$

Barack Rodos \& Bacine

$4.7 \%$

Total:

In short, some firms rose and others fell, presumably in line with their ability to win lead plaintiff designations, but in total there has been only a small (4\%) decline in the concentration level. Moreover, this modest shift in the direction of greater competition may have been more than offset by the increased need of plaintiff's law firms to pool their clients to win the coveted lead plaintiff status and by the development of "repeat relationships." From a competitive standpoint, the market for class counsel services has basically remained static before and after the PSLRA.

Of course, the modest nature of the above changes would mean little if lead plaintiffs were doing more for the class, achieving either larger settlements or recovering a higher percentage of the class members' losses. Such data, however, seems largely lacking. Professors Cox and Thomas found in 2006 that the ratio of settlement amounts to estimated provable losses in securities class actions has actually declined since the passage of the PSLRA ${ }^{38}$ and that settlement size also did not increase following the PSLRA. ${ }^{39}$ Although they found

37 Choi \& Thompson, supra note 33, at 1515.

38 See Cox \& Thomas with Kiku, supra note 36 , at 1627.

39 The mean settlement size did increase from $\$ 9,734,000$ to $\$ 15,728,000$, but the "median" settlement size rose only from $\$ 5,500,000$ to $\$ 5,745,000$. Id at 1624 . Both shifts may be largely the consequence of inflation and the increased size of the market capitalization of defendant corporations in the post-PSLRA period. Cox and Thomas find that overall settlement size did not 
some evidence that institutional lead plaintiffs did better for their class members in terms of settlement size as compared with other categories of lead plaintiffs, ${ }^{40}$ this finding was more than offset by their more pessimistic finding that "institutional lead plaintiffs have the lowest average and median recovery percentages of any group." 41 Taken together, these twin facts suggest that institutional lead plaintiffs simply gravitate towards the larger case.

Equally striking was Professors Cox and Thomas's finding that individuals continue to be lead plaintiffs in the plurality of cases. They report that single institutions and combinations of institutions with individuals accounted for only $18 \%$ of the cases in their post-PSLRA sample, while groups of individuals accounted for $41 \%$ of post-PSLRA settlements. ${ }^{42}$ This suggests both that the desire of institutions to serve as lead plaintiff has been modest and that law firms were happy to aggregate clients on any basis they could.

What then is the bottom line? Once they controlled for all obvious variables, Professors Cox and Thomas report that "post-PSLRA settlements are not statistically different from those in the pre-PSLRA period."43 Thus, they conclude:

"These results suggest that the enactment of the PSLRA had no significant impact on settlement size."44

Worse yet, they find that:

"Investors appear to be recovering a smaller percentage of their losses today than they did before the passage of the PSLRA." 45

Nor does it appear likely that institutions will eventually serve as lead plaintiffs in most cases. Institutional lead plaintiffs, Cox and Thomas conclude, are "very selective" in their choice of cases, agreeing to serve as lead plaintiffs only in the largest cases with the potentially greatest damages. ${ }^{46}$ Although Professors Cox and Thomas remain optimistic about the ability of institutions to improve settlements, the problem that confounds their optimism is that institutions may find that they can do even better for themselves by opting out. Overall, although the PSLRA has changed securities litigation, there is little evidence that it has yet improved investor welfare or even enhanced competition.

\footnotetext{
change in any statistically significant way. Id. at 1637.

$40 \mathrm{Id}$. at 1624 . The fact that institutional plaintiffs tend to serve in larger cases against larger defendants probably explains this finding. Id. at 1625-26.

41 Id. at 1627.

42 Id. at 1623 .

43 Id. at $1628-29$.

44 Id. at 1629.

45 Id. at 1637.

46 Id. at 1629 .
} 


\section{THE "EXIT" AlternAtive}

\section{A. The New Trend Toward Opting Out}

For decades, institutions did not opt out. Nor did they serve as class representatives. Rather, they simply remained passive. Only with the PSLRA did they face a need to consider their position with respect to securities litigation. In the wake of the PSLRA, they were regularly lectured by both plaintiffs' and defense counsels that to opt out would be disloyal and selfish - an attempt to steal an advantage over smaller class members. Over the years, this author has sat on a number of panels at conferences organized for institutional investors by prominent plaintiffs' law firms. After suitable wining and dining, the institutional officials would hear panels of experts debate current issues. But eventually, at some point, plaintiff's counsel and defense counsel would link arms and explain in common the fallacy of opting out. Institutional opt outs would force defendants to reserve funds for the opt out actions, they would explain, and this would slow and reduce the recovery in the class action. In the long run, they would conclude, all investors would be worse off.

For a time, this jawboning worked. But it appears to have broken down as plaintiffs' firms developed ongoing "repeat relationships" with particular institutional investors who were willing to serve as lead plaintiffs. Once these relationships developed, it became easier for the plaintiff's law firm to approach its clients when the law firm lost the contest for class counsel and to suggest that they proceed on an individual basis in state court. Logically, the plaintiff's law firm has every incentive to solicit its client pension funds to opt out and sue in state court because that was the only course of action that would likely yield it any fee. But why did the client follow? Possibly, the pension funds trusted these law firms with whom they now had established relationships, or possibly more problematic "pay-to-play" practices induced the clients to take their lawyers' advice. In some cases, the clients may simply have been outraged over how little they would receive in the class settlement. Whatever the institutions' particular motivations, their experience serving as a lead plaintiff under the PSLRA's provisions seems likely to have been at least a "but for" cause of this new phenomenon.

Changes in the case law may also have facilitated this development. Once, the federal judge handling the class action could use the All Writs Act to prevent any individual opt out action in state court from proceeding to trial on the grounds that an imminent trial in state court might jeopardize the settlement in federal court. This was 
the seeming implication of In re Baldwin-United Corp. ${ }^{47}$ which had upheld the federal court's power to enjoin state trials likely to disrupt any pending settlement. This changed with the WorldCom litigation, in which Judge Denise Cote sought to bar a state court trial in Alabama in a case brought by opt out plaintiffs on these grounds and was overturned in 2004 by the Second Circuit, which found that a District Court could not enjoin a state trial simply because it was likely to delay the scheduled trial in federal court. ${ }^{48}$ It is uncertain whether this decision encouraged other institutions to opt out, but, at least for the future, opt outs seem more able to proceed to trial without serious fear of federal court intervention.

The first major securities case in which numerous class members were solicited to opt out appears to have been WorldCom, and the instigator was the redoubtable William Lerach. His firm had lost the contest to become class counsel in the WorldCom class action to the Bernstein, Litowitz firm (largely because the New York State Pension Fund, which was represented by Bernstein, Litowitz, held a very large position in WorldCom's bonds). Rather than simply play a subsidiary role in the class action, Mr. Lerach convinced some 65 investors to opt out of the WorldCom action. ${ }^{49}$ Although the WorldCom class action eventually settled for $\$ 6.2$ billion, at the time a record amount, the opt outs have claimed to have done much better. In 2005, three large California pension funds-CalPERS, CalSTRS, and the Los Angeles County Employee Retirement System-announced that they had settled their opt-out claims for $\$ 257.4$ million. ${ }^{50}$ Five New York City pension funds similarly opted out and settled their $\$ 130$ million in claims for $\$ 78.9$ million, and their counsel announced that this settlement amounted to "three times more than they would have recovered if they had joined the class." 51 These claims have been disputed by class counsel in WorldCom, and this essay will not attempt to resolve this dispute. Whatever the reality, the WorldCom opt outs were a signal to the institutional investor community that they could possibly do better

47770 F.2d 328, 335 (2d Cir. 1985).

48 See Ret. Sys. v. J.P. Morgan Chase \& Co., 386 F.3d 419 (2d Cir. 2004). The decision has murky edges, because some weight was placed on the allegedly distinguishing fact that no settlement was imminent in WorldCom whereas it had been in Baldwin-United. At the same time, the Second Circuit did permit the removal of individual bondholder suits from state court to federal court despite an express anti-removal provision in the Securities Act of 1933. See Cal. Pub. Employees Ret. Sys. v. Worldcom, Inc., 368 F.3d 86 (2d Cir. 2004). Here, however, the Second Circuit was protecting the power of the bankruptcy court to assume control over related cases.

49 See Kevin LaCroix, Opt-Outs: A Worrisome Trend in Securities Class Action Litigation, INSIGHTS, April 2007.

50 Id. at 3.

51 Id. For a similar estimate, see David Lenckus, Individual Suits Likely Over Subprime Losses; Some Investors Expected to Opt Out of Class Actions, BUSINESS INSURANCE, Nov. 19, 2007. 
by opting out.

If WorldCom was the beginning, the case that truly marked the floodgates opening wide on opting out was the AOL Time Warner class action, which settled on a class basis in 2006 for $\$ 2.4$ billion-again a landmark settlement. This time, Mr. Lerach convinced more than one hundred investors to pursue individual opt out actions. ${ }^{52}$ Based on a variety of press reports, these opt outs appear to have done significantly better than if they had stayed in the class, with the University of California settling for $\$ 246$ million, the Ohio State Pension Funds for $\$ 144$ million, CalPERS for $\$ 117.7$ million, and CalSTRS for $\$ 105$ million. ${ }^{53}$ As each opt out settled, they announced how much better they had done than if they had participated in the class. For example, the State of Alaska settled its $\$ 60$ million claim for $\$ 50$ million and said that it had done "50 times what we would have recovered from the class." 54 CalPERS claimed losses of approximately $\$ 129$ million, so its settlement for $\$ 117.7$ million represents a seeming $90 \%$ recovery rate. Such recoveries (between $80 \%$ and $90 \%$ in the cases of Alaska and CalPERS) not only vastly exceed the typical $2 \%$ to $3 \%$ recovery rate in most securities class actions, but are much higher than the settlement ratio in any form of private civil litigation. CalPERS's general counsel described its settlement as "approximately 17 times what we would have recovered if we stayed in the class," estimating that it would have received only $\$ 6$ million under the class action; ${ }^{55}$ similarly, CalSTRS estimated that it would have received only $\$ 15$ million under the class action (but received $\$ 105$ million to settle its opt-out action). ${ }^{56}$ The University of California estimated that it did "16 to 24 times" better than what it would have received under the class settlement. ${ }^{57}$ The State of Ohio's Attorney General estimated that his state's five pension funds (which received $\$ 144$ million plus $\$ 31$ million in legal fees and expenses) received $\$ 135$ million more than they would have received under the class settlement. ${ }^{58}$ These are not small differences.

If $A O L$ Time Warner showed that the floodgates had opened for opt outs, the Qwest class action holds the dubious honor of being the

52 See Josh Gerstein, Investors Opt Out of Time Warner Class Action Suit, N.Y. SUN, Feb. 8, 2006 , at 5 .

53 See LaCroix, supra note 49; Gilbert Chan, CalPERS' Time Strategy Pays Off: The state pension fund gets $\$ 117.7$ million after opting out of class action against media giant, SACRAMENTO BEE, Mar. 15, 2007. Pat Coughlin, counsel to the opt outs, has estimated that they did "20 times" better than under the class. See Lenckus, supra note 51.

54 See Josh Gerstein, Time Warner Case Finds a Surprise, N.Y. SuN, Dec. 7, 2006, at 1; see also LaCroix, supra note 49.

55 Chan, supra note 53 (quoting Peter Nixon, CalPERS' general counsel).

56 Id.

57 Id. (quoting Christopher Patti, an in-house attorney for the University).

58 See Time Warner Settles Lawsuit for \$144 Million," L.A. TIMES, Mar. 8, 2007, at C6 (quoting Ohio Attorney General Marc Dann). 
first in which the total payments to opt outs actually exceeded those to the class. The Qwest class action settled in 2005 for $\$ 400$ million, ${ }^{59}$ but to date Qwest has disclosed payments of $\$ 411$ million to opt outs. ${ }^{60}$ In late November, 2007, the Alaska Attorney General issued a press release announcing that the state's various funds had settled their $\$ 89$ million in claims in the Qwest litigation for a net recovery (after attorneys' fees) of $\$ 19$ million and that this recovery contrasted with a payment of only $\$ 427,000$ that they would have received under the class settlement. 61 This is roughly a 45:1 ratio. Similarly, the Teachers Retirement System of Texas announced a $\$ 61.6$ million net recovery and contrasted it with a $\$ 1.4$ million payment that it would have received under the class action settlement. ${ }^{62}$ CalSTRS settled for $\$ 46.5$ million and announced that it was receiving "about 30 times more than it would have recovered if it had taken part in the class action."63

This pattern has continued to accelerate in late 2007 and early 2008. A dramatic example is the Tyco International class action, which settled in December 2007 for $\$ 3.2$ billion. $^{64}$ But, even in this near record settlement, the court's order approving the settlement listed some 288 opt outs. ${ }^{65}$ Most of these opt outs appear to have been mutual funds, ${ }^{66}$ which is itself a significant development because it shows that the plaintiff's bar has now built a bridge to more traditional sectors of the investment community (and not just public pension funds). Once, mutual funds appear to have disdained to claim even their share of the recovery, ${ }^{67}$ but today they are actively pursuing litigation on their own. The counsel representing these institutional opt outs included many of the leading firms in class action bar: Bernstein, Litowitz, Berger \& Grossmann; Lowey Dannenberg; and Lieff, Cabraser Heimann \& Bernstein. ${ }^{68}$ Having now developed relationships with both mutual

59 The stipulation of settlement was filed on November 23, 2005. See In re Qwest Communications Int'l Inc. Sec. Litig., 2006 U.S. Dist. LEXIS 71267, No. 01-cv-01451-REBCBS, at *8 (D. Colo. Sept. 26, 2006).

60 See Robert Elder, Retired Teachers System, Qwest Reach Settlement, AUSTIN AM. StATESMAN, Dec. 6, 2007 at D1; see also Kevin LaCroix, Opt-Outs, Claims Severity and D\&O Insurance Limits, D\&O DIARY, Feb. 5, 2007, available at http://dandodiary.blogspot.com.

61 See Press Release, Alaska Dep't of Law, Department of Law Announces \$19 Million Settlement in Securities Fraud Claims Against Qwest Communications (Nov. 21, 2007), available at $\mathrm{http}: / / \mathrm{www}$. law.state.ak.us/pdf/civil/SecureQwestCommunication.pdf.

62 See Elder, supra note 60 . This would be better than a $40: 1$ ratio.

63 See LaCroix, supra note 60.

64 See 3.2 Billion Settlement in Class Action Against Tyco and PricewaterhouseCoopers Approved, Class ACTION MONITOR, Jan. 15, 2008. Tyco paid $\$ 2.95$ billion, and PricewaterhouseCoopers contributed $\$ 225$ million to this settlement.

65 See In re Tyco Int'l Ltd. Sec. Litig., No. 02-1335-PB, 2007 U.S. Dist. LEXIS 95199 (D.N.H. Dec. 19, 2007).

66 Id.; see also The Tyco Opt Out Cases Continue to Trickle In, SEC. LITIG. WATCH, Feb. 11 , 2008, available at http://slw.riskmetrics.com (listing the mutual fund families opting out).

67 See Cox \& Thomas, supra note 27, at 871-78.

68 See Tyco, supra note 66. 
funds and pension funds, these firms can predictably solicit class members to opt out in any case in which they are not chosen as class counsel.

Will institutional investors do better than if they stayed in the class? Although one cannot predict outcomes with confidence, the first individual suit against Tyco has recently settled for $\$ 73.3$ million, and it was brought by New Jersey's public pension funds. ${ }^{69}$ Such a recovery seemingly exceeds what New Jersey's share of the class action settlement would have been. ${ }^{70}$

For the immediate future, securities litigation is likely to be dominated by cases growing out of the subprime mortgage debacle, and cases asserting such claims are now being filed at a potentially record rate. These cases are particularly likely to produce a high rate of opt outs because, typically, the class consists of debt purchasers who bought collateralized debt obligations ("CDOs") from underwriters in registered public offerings. Such debt purchasers are characteristically institutional investors. Moreover, the Securities Act of 1933 (unlike the Securities Exchange Act of 1934) confers concurrent jurisdiction on state courts and even contains an anti-removal provision that prevents the defendant from returning the case to federal court. ${ }^{71}$

Premature as it may still be to conclude what the ultimate impact will be of increased opting out on the securities class action, the prospect at least is imaginable today that the securities class action may be relegated to a secondary role: that of serving as a vehicle of last resort for smaller retail investors. To be sure, opting out is only economically viable when the individual claim exceeds some minimum level, but that minimum level may also decline further as the procedures for forming opt out coalitions become better established.

\section{B. Why Do Opt Outs Do Better?}

Class counsel dispute whether opt outs invariably do better than those who remain in the class, and the ratios by which the individual recoveries paid to the opt outs exceeded their prorated share of the class recovery may have been exaggerated in some cases. Nonetheless, opt outs clearly seem to be doing better. What explains this pattern? At least three basically legal reasons and two additional economic reasons

69 See Tyco International Ltd., WALL ST. J., Apr. 30, 2008, at A14; see also Joseph DiStefano, New Jersey to Collect From, Pay Tyco, PhILAdelPHIA InQuiRer, May 1, 2008, at C6.

70 This $\$ 73.3$ million recovery represents over $2.2 \%$ of the $\$ 3$ billion class action settlement. Unless the New Jersey pension funds owned more than that percentage of Tyco's securities, (which seems unlikely), they would appear to have received a larger recovery than their proportionate share of the class action settlement (and thus to have outperformed the class action).

71 See Securities Act of 1933 \&22(a), 15 U.S.C. $\$ 77 v(a)(2000)$. 
can be plausibly offered to explain the superior performance of opt outs:

\section{Legal Reasons}

\section{a. Escaping Federal Restraints}

First, by opting out and suing in state court, plaintiffs can escape obstacles that either uniquely apply to class actions or to securities actions in federal court. The most obvious example is the Private Securities Litigation Reform Act ("PSLRA"), whose provisions, including its stay on discovery, its heightened pleading standards, and a presumption in favor of cost shifting against the plaintiff, apply only in federal court. Also, state "blue sky" statutes often do not require plaintiffs to plead or prove scienter.

To prevent plaintiffs from escaping the PSLRA by simply shifting their suits to state court, Congress passed the Securities Litigation Uniform Standards Act ("SLUSA") in 1998, which did indeed stop the migration of class actions from federal to state court. But SLUSA's absolute bar applies only to class actions and consolidated proceedings involving 50 or more plaintiffs. As long as institutions sue in smaller groups, they avoid most of SLUSA's reach. The one exception to this generalization is that SLUSA does broadly authorize the federal court to stay discovery in a state court "upon a proper showing," even in a nonclass action. ${ }^{72}$ This provision is not automatic (as the stay under the PSLRA is), and some federal courts have read it conservatively. ${ }^{73}$ Still, SLUSA's stay of state court discovery is not a practical deterrent to opt outs, because most class members opt out only after a settlement has been reached in federal court (when the stay is no longer applicable). Thus, the state court litigant who opts out of the federal class can

72 Section 21D(b)(3)(D) of the Securities Exchange Act of 1934, 15 U.S.C. $₹ 78 \mathrm{u}-4$ (b)(3)(D) authorizes a federal court as follows: "Upon a proper showing, a court may stay discovery proceedings in any private action in a State court, as necessary in aid of its jurisdiction, or to protect or effectuate its judgments, in an action subject to a stay of discovery pursuant to this paragraph." This provision is less automatic than the PSLRA's stay, which requires no special showing.

73 The cases are divided as to when a stay should be granted of discovery in a state court action that purports to be something other than a securities fraud action (for example, a derivative action). For cases granting a stay of state court discovery, see Newby v. Enron Corp., 338 F.3d 467 (5th Cir. 2003) (upholding stay under Section 21D(b)(3)(D) of the Securities Exchange Act of 1934 in case where state action was not a class action); Spears v. Metropolitan Life Ins., No. 2:07-cv-00088-RL-PRC, 2007 U.S. Dist. LEXIS 37004 (N.D. Ind. May 17, 2007) (granting stay even where state action was for breach of fiduciary duty, not fraud); In re Cardinal Health, Inc. Securities Litigation, 365 F. Supp. 2d 866 (S.D. Ohio 2006). For a case refusing to grant a stay on the ground that the state court action had a different (non-fraud) focus, see City of Austin Police Retirement System v. ITT Educational Services, No. 1:04-cv-0380-DFH-TAB, 2005 U.S. Dist. LEXIS 1646 (S.D. Ind. February 2, 2005). 
proceed to trial quickly in state court.

The PSLRA is not the only obstacle avoided by opting out and suing in state court. Class action certification standards have been significantly tightened across the spectrum of federal court litigation over recent years, and, surprisingly, the most dramatic changes have been in the area of securities class actions. ${ }^{74}$ Once, securities class actions were almost automatically certified, but more recently they have been denied certification on a variety of grounds. These problems disappear if an action is brought on a non-class basis in state court, and, with no certification decision looming as a barrier, the time necessary to reach the trial stage (and hence settlement) may be substantially shortened.

Bringing the action as an individual action also simplifies the problems associated with proving reliance. In federal court in a class action, the plaintiffs can seek to rely on the "fraud on the market" doctrine, but the circumstances under which that doctrine can be invoked have narrowed, as courts are increasingly finding the market not to be efficient in particular stocks, thereby rendering that doctrine inapplicable. ${ }^{75}$ But these problems drop out of the picture in a state court trial of an individual action, as the plaintiff institution can simply present evidence that its employees in fact relied upon the defendant's public statements. Defendants may suspect that this testimony is selfserving and fabricated, but that is nearly impossible to prove.

\section{b. A More Favorable Forum}

A second general category of reasons for the increase in opt outs involves the likelihood that a state court may be a more attractive forum for many institutions. Imagine that your client is a pension fund for the public school teachers in a Midwestern state. In federal court, your client would be submerged in a sea of institutions, but in state court the plaintiff's attorneys can open their case by focusing the jury on poor Mrs. Jones, the second grade school teacher for their children, who will soon retire with a deflated pension because of the substantial losses suffered on the defendant's stock. "Won't you help Mrs. Jones get her pension back," they can ask, "by punishing those crooks from New York?" In short, the case becomes more graphic and appealing. Not only is there a decided home court advantage when a public pension

74 See, e.g., Oscar Private Equity Invs. v. Allegiance Telecom, Inc., 487 F.3d 261 (5th Cir. 2007); Regents of the Univ. of Cal. v. Credit Suisse First Boston, 482 F.3d 372 (5th Cir. 2007); In re Initial Pub. Offering Sec. Litig., 471 F.3d 24 (2d Cir. 2006).

75 See, e.g., In re PolyMedica Corp. Sec. Litig., 432 F.3d 1 (1st Cir. 2005); Unger v. Amedisys Inc., 401 F.3d 316 (5th Cir. 2005). 
fund can sue in its own jurisdiction, but elected state judges are seldom oblivious to the plaintiff's identity.

\section{c. Insolvency Constraints}

A third (and possibly the most significant) reason is that the settlement of opt out cases is seldom insolvency constrained. As a practical matter, the defendant in the state court action cannot utilize its limited solvency as a defense or threaten a bankruptcy filing. In contrast, a "mega" securities class action in federal court may hypothetically seek $\$ 5$ billion in damages, and the defendants' strongest argument may be that the corporation simply cannot pay such an amount and would file for bankruptcy before doing so. Similarly, the federal judge and/or a mediator may push for a settlement within a "realistic" range. But, if instead an individual action is brought in state court, the maximum damages will be much smaller. Few major corporations can seriously threaten to turn to bankruptcy to avoid only a $\$ 100$ million claim. The success of opt outs thus illustrates the tyranny of small decisions. No individual opt out is required to be "reasonable," but class counsel often can be compelled to moderate its demands.

\section{Economic Reasons}

\section{a. Agency Costs}

Opt outs may do better because they face greatly reduced agency costs. Most obviously, each opt out selects its own counsel and can monitor it closely, demanding at least as good a settlement as the other opt outs receive. If unsatisfied, it can go to trial. An absentee class member has no similar choice.

This is an inherent problem in the class action, because its disparate members may have very different preferences, expectations, and estimates. Even an ideally loyal class counsel cannot satisfy all their preferences. In an individual action, agency costs can be reduced by specially tailored compensation formulas. In particular, although the plaintiff's attorney in a class action will likely be compensated on the basis of a declining percentage of the recovery basis, which reduces its incentive to hold out for a larger recovery, the plaintiff's attorney in the individual action can negotiate its fee with its clients, and sometimes even an increasing percentage of the recovery formula may be used.

Beyond this point, there is a further difficulty with the securities class action. Essentially, it requires the class member to rely on two 
sets of agents: (1) the lead plaintiff, and (2) the class counsel. Each may have its own misincentives. The lead plaintiff may be a public pension fund whose elected state official needs to receive political campaign contributions, or the official may prefer favorable publicity to maximizing the monetary recovery. Even if the lead plaintiff has the same incentives as more economically oriented investors, class counsel may still possess substantial discretion, because pension funds often have little in-house expertise in litigation tactics or strategy. In contrast, the opt-out hires its own agent and is in a better position to monitor this agent.

\section{b. Economic Leverage and Voting Power}

Institutional investors typically hold significant voting power. Suppose three large California pension funds opt out together, holding collectively $6 \%$ of the firm's stock. They can vote this stock against management or potentially team up with a Carl Icahn-style insurgent to threaten management with ouster. Thus, management has reasons to placate them that do not apply to smaller shareholders, and this can translate into a higher settlement.

More generally, the large indexed institutional investor-such as a CalPERS or a TIAA-CREF-is understood by management to be a permanent presence in their corporate governance. Unlike non-indexed investors, it is there for the duration and so must be dealt with. Knowing this, the corporation has more reason to placate such a shareholder. As a result, litigation often need not even be commenced before a settlement is reached.

\section{Opts Out in Other Varieties of Class Actions}

The relative success of opt outs in securities class litigation in comparison to class members is hardly unique. In antitrust litigation, large commercial buyers have recurrently opted out of the class and sued in individual actions, sometimes combining to file a consolidated complaint. Useful examples are provided by two major antitrust class actions brought against Archer-Daniels-Midland Co. ("ADM"). In 1997 , following its criminal conviction for price fixing, ADM reached a civil settlement with class action plaintiffs in a suit alleging price-fixing in the citric acid market under which ADM paid $\$ 86$ million, but some of the largest purchasers, including Proctor \& Gamble, Quaker Oats, 
and the Kraft Foods unit of Philip Morris Cos. opted out. ${ }^{76}$ A year later, ADM was forced to reveal that it had paid \$36 million to four of these opt out firms, and one careful study has estimated that the opt outs received "from 2.0 to 3.5 times more damages (per dollar of citric acid purchased) than did the settling class." 77 Earlier, ADM also was independently sued for price-fixing in the lysine acid market (lysine acid being an amino acid used by food companies and feedlots to promote quick growth in hogs and chickens). Again, it settled the class action for $\$ 45$ million (after paying a $\$ 70$ million criminal fine to the Department of Justice), but, again, some twenty-five large customers opted out. ${ }^{78}$ While the actual amounts paid to these opt outs is not known, one study has estimated that they would receive "about $\$ 20$ million"- again outperforming class members. ${ }^{79}$

The ADM case is in no sense unique. In one of the largest antitrust class actions, the major vitamin producers first pled guilty to antitrust price fixing charges and then paid $\$ 1.17$ billion in an antitrust class action settlement. But again over 200 corporations, including large firms such as Tyson Foods and Quaker Oats, chose to opt out of the class of over 4,000 plaintiffs and sue individually. ${ }^{80}$ These opt outs were reported to account for over $70 \%$ of the class in terms of the volume of their purchases. ${ }^{81}$ The likelihood is high that in opting out these sophisticated plaintiffs made an intelligent decision about their own best interests. Logically, one should assume that, when $70 \%$ of the claims opt out, this was not a complete surprise to class counsel; rather, both sides may have structured the class action as the vehicle for compensating the residual and less sophisticated plaintiff.

In mass torts class action settlements, opting out is an even more established pattern. Some 90,000 persons opted out of the diet drug (or "Fen-Phen") settlement reached by Wyeth. ${ }^{82}$ Characteristically, such opt outs have higher than average value claims, and in mass tort cases, the variation in claim value can be particularly great, based on the highly variable physical injuries suffered by the plaintiffs. In mass

76 See P\&G, Quaker Oats, United of Philip Morris Sue Archer-Daniels, WALL ST. J., June 11, 1997, at B15.

77 See John M. Connor, Archer-Daniel-Midland: Price-Fixer to the World 39 (Purdue Univ. Dept. of Agric. Econ. Staff Paper 98-100, 1998).

78 See Thomas Burton, Several ADM Clients Won't Participate in a Proposed Price-Fixing Settlement, WALL ST. J., July 10, 1996, at B2.

79 See O'Connor, supra note 77 , at 38.

80 See Carlos Tejada, Some Plaintiffs Quit Settlements in Vitamin Case, WALL ST. J., Feb. 18, 2000 , at B10. For a discussion of the opt out procedures in this case, see In re: Vitamins Antitrust Class Actions, 327 F.3d 1207 (D.C. Cir. 2003). The background of the case is more fully discussed in In re: Vitamins Antitrust Class Actions, 215 F.3d 26 (D.C. Cir. 2000).

81 See Tejada, supra note 80.

82 See Scott Hensley, Wyeth Says 90,000 Opt Out of 'Fen-Phen' Pact, Wall ST. J., May 16, 2003 , at B4. 
torts, the class action tends to become the repository for plaintiffs whose claims either have evidentiary, factual or legal problems that make it undesirable for them to proceed on an individual basis or simply have below average market value.

The same pattern then seems to prevail across a variety of contexts: opt outs either hold higher value claims or have large claims, which they are unwilling to entrust to a class counsel over whom they have little control.

\section{IMPLICATIONS}

The dramatic disparity between the opt out recoveries and the class recovery raises several basic questions: (1) When can institutional investors be persuaded to remain in the class action?; (2) What can defendants do to deter opting out (and how should courts respond to these efforts)?; (3) At what point are institutional investors legally obligated to opt out, rather than serve as a lead plaintiff?; and, finally, (4) What does the increased rate of opt outs imply for the future of the securities class action? This last question translates into a deeper issue about equity. If defendants reduce their settlement offers to the class or restructure the settlement terms to deal with large scale opt outs, will small retail shareholders be made worse off by the fact that institutional investors are increasing their recoveries? In effect, will the new trend produce a zero-sum outcome in which institutions gain at the expense of smaller retail investors who cannot flee the class action?

\section{A. When Can Institutions Be Persuaded to Stay in the Class?}

Although events may be moving in the direction of a two-track system in which institutions will opt out while smaller investors remain in the class, the pattern is not uniform. Institutions did remain within the Enron class. Possibly, this was based on their confidence in William Lerach as their class counsel, or possibly it was based on the absence of competing solicitations (as Enron did face serious legal issues and was ultimately decertified-but not before settlements from some of the defendants exceeded $\$ 7$ billion, an all-time record).

Where, then, is the breakpoint below which opting out becomes infeasible? Mr. Lerach's former partner, Patrick Coughlin, has estimated that opting out only makes sense when the claimed damages exceed $\$ 1$ billion. ${ }^{83}$ But this estimate seems high. Over time, lower 
cost competitors will almost certainly surface within the plaintiff's bar that are willing to undertake suit for opt out claimants with much smaller losses. Hypothetically, if an opt out counsel could aggregate a half-dozen claimants into a consolidated action in state court seeking, say, $\$ 50$ million in damages and could settle that case for, say, $\$ 20$ million, it could charge a negotiated fee of $331 / 3 \%$ (or $\$ 6.67$ million) and still earn an acceptable return. No judicial approval of the fee is required in such a consolidated action (as no class action is involved), and this eliminates the inevitable uncertainty surrounding the fee award that faces counsel in a federal court class action (where judicial approval of both the settlement and the fee award is mandatory).

What will disincline an institution to opt out? Ironically, the factor that may most deter opting out is the action's lack of merit. If the action faces serious legal or factual problems, few institutions will likely want to assert these claims on their own, both because of the prospective reputational injury if the case is dismissed and the wasted investment of time and money. Staying in the herd is not only safer and less costly, but it may increase the chance of a favorable settlement, because the greater size of the class may constitute a more potent threat. That is, a defendant might rationally be willing to litigate individually with ten different institutions, each suing on a $\$ 100$ million claim in a different forum, but feel compelled to settle a class action seeking $\$ 2$ billion in damages because an adverse outcome in the latter case would be bankrupting.

Another motivation for staying in the class may be a differential in the expected attorneys' fees. Because the opt out counsel is likely spending the same approximate time on the case as the class action counsel but is facing a smaller recovery, it will predictably seek to charge a higher percentage fee. Also, in smaller cases, opt out counsel may also want the institution to bear the out-of-pocket costs of the litigation. Institutions that opt out will face other problems as well. First, the institution can expect to be aggressively deposed by the defendants. For some institutions (for example, hedge funds), there could be a risk of embarrassment, or worse, if their own trading activities were examined. Defendants may even seek to assert counterclaims in some cases against particular institutions (such as hedge funds). In contrast, an institutional investor can hide in the crowd in a class action and maintain its anonymity. Second, an institution that opts out will probably also face a greater risk of a litigation defeat because the defendants will not be as deterred from going to trial in a smaller case as in a multi-billion dollar class action. The institution that wants an assured recovery knows that few class actions ever go to trial.

Still, the bottom line is likely to be that there is little that class counsel can do to keep the very large institution with losses above, say, 
$\$ 100$ million in the class action. But competition between class and opt out counsel does seem realistic for those institutions with losses of a smaller magnitude. Not only will opting out require a higher fee, but it exposes such an institution to adversarial tactics intended to harass and to the possibility of an individual litigation defeat (which could focus criticism on it that it would not incur if it remained within the class).

\section{B. What Can Defendants Do to Deter Opting Out?}

To date, opt outs have largely occurred after a class action settlement has been reached. Few institutions have opted out at the outset, but rather have waited to see what proposed settlement emerged. Only if it seemed inadequate would they then opt out in response. In this light, an obvious strategy for defendants comes into focus: advance the time of the opt out decision so that it must be made before any settlement is reached. Once a settlement is proposed, opting out often becomes a "no brainer" decision for the larger institution who views its prorated share of the recovery as inadequate, but at an earlier stage many institutions might be reluctant to incur costs when the class settlement could potentially be attractive. Thus, if the defendants can arrange for an early certification decision well before settlement discussions have begun, two outcomes are possible: (1) they might succeed and convince the court that the class cannot be certified; or (2) failing that, they might still cause the institutions within the class to permit the opt out period to expire without taking any action. The result is to lock class members within the class and permit a less attractive settlement to then be negotiated. In truth, class counsel might cooperate in such a strategy with defendants because opt outs will also reduce its fee (assuming that the settlement is reduced pro rata by the claims of the opt outs).

More coercive tactics are also possible. Class counsel and defense counsel could structure a settlement under which the class members receive a priority over any individual recoveries. For example, if the class action settles first (as is typical), the class members could be given a security interest that makes them secured creditors and thus gives them a priority in bankruptcy. Then, if the opt outs filed numerous individual actions and the corporation did file for bankruptcy, the class members would rank at the front of the line, whereas the individual opt out claims would be at the rear end. Obviously, this tactic would be used only when the combination of the class action and the individual actions exposed the corporation to insolvency, but the beauty of this approach is that the defendant corporation might never need to file for bankruptcy. Potential opt outs would understand from the outset the 
risk that they would stand behind the class action claimants in the bankruptcy queue, and this might deter them from opting out.

The one tactic to discourage opt outs that has been litigated (and upheld) involves adding a provision to the class action settlement entitling the class members to an increase in their recovery if a higher settlement is reached over a specified duration with any opt outs. ${ }^{84}$ Effectively, such a provision pressures the defendants not to settle with the opt outs on superior terms-by subjecting them to enormous liability to the class, if they do. Such a "most favored nations" clause is, however, risky because as a practical matter it forces defendants to go to trial and risk greater exposure. Sometimes, such a provision may arguably represent a collusive agreement among defendants not to settle with opt outs, but at least it does not reduce the recovery to class members.

\section{Does ERISA Compel the Institutional Investor to Opt Out?}

A plausible case can be made that the institutional investor who has the opportunity to opt out is under a legal obligation to do so. ERISA's "exclusive benefit" standard requires the fiduciary of an "employee benefit plan" to "discharge his duties with respect to a plan solely in the interests of the participants and beneficiaries and (A) for the exclusive purpose of: (1) providing benefits to participants and their beneficiaries; and (2) defraying reasonable expenses of administering the plan." 85 Thus, this exclusive benefit rule means that it would be inappropriate for a pension plan subject to ERISA to serve as a lead plaintiff in a class action in order to benefit the other class members. Such a public-spirited desire to lead the class and achieve a superior settlement is an impermissible justification because it conflicts with the fiduciary's obligation to act for the "exclusive benefit" of the pension plan's participants and their beneficiaries, rather than for the interests of other class members.

Of course, it may be impossible for the pension plan to find counsel willing to undertake its case on a reasonable contingent fee basis. Or, the fees sought by the opt out counsel may be higher than that which class counsel would charge. Or, the pension plan may appraise the risk of a litigation defeat or a costly counterclaim as being unacceptably higher in the opt out case. All these reasons could easily support a decision not to opt out. The limited case law under ERISA

84 See In re: Vitamins Antitrust Class Actions, 215 F.3d 26 (finding that opt outs lacked standing to challenge this provision).

85 See Employee Retirement Income Security Act of $1974 \S 404(a), 29$ U.S.C. $\S 1104(a)$ (2000). 
has held that a fiduciary does not breach its duty to the pension fund by failing to enforce a claim if the fiduciary reasonably believed that to do so would be futile. ${ }^{86}$

Legal risks might arise, however, if the real reason for the pension plan's decision not to opt out were some personal benefit to its trustee or directors, such as the receipt of "pay for play" political contributions from class counsel. Obviously, this would violate ERISA's "exclusive benefit" standard, if it were applicable. Still, public pension funds are not subject to ERISA, which expressly excludes them. ${ }^{87}$

Nonetheless, this exclusion of public pension funds from ERISA may amount only to a distinction without an effective difference. In 1997, the National Conference of Commissioners on Uniform State Laws adopted the Uniform Management of Public Employee Retirement Systems Act (the "Act"), which is in the process of being widely adopted. ${ }^{88}$ The Act's provisions were modeled after ERISA, ${ }^{89}$ and it contains its own "exclusive benefit" rule. ${ }^{90}$ Even where the Act or other state statutes are not applicable, public pension fund fiduciaries are still subject to the common law standards for fiduciaries, and these standards are probably not significantly different. At a minimum, they require that the trustee "use reasonable care and skill to preserve the trust property." 91 Spurning a probably higher recovery to stay in the class and receive a settlement typically amounting to between $2 \%$ and $3 \%$ of your losses does not sound prudent, unless a specific reason is given.

This scenario of potential liability for pension plan fiduciaries who do not opt out probably becomes most plausible when (a) a plaintiff's law firm solicits the pension plan to opt out and proposes competitive terms, (b) other funds do opt out, and (c) the individual pension fund documents no contemporaneous decision as to why it declined to opt

86 See, e.g., McMahon v. McDowell, 794 F.2d 100, 110 (3rd Cir. 1986).

87 See 29 U.S.C. $\$ 1003$ (b) (excluding "governmental plans" from ERISA's coverage).

88 For an overview of this statute, written by the Reporter who drafted it, see Steven L. Willborn, Public Pensions and the Uniform Management of Public Employee Retirement Systems Act, 51 RUTGERS L. REV. 141 (1998).

89 Id. at 145 .

90 Section 7 of the Act requires a trustee or other fiduciary to "discharge duties with respect to [the] retirement system: (1) solely in the interest of the participants and beneficiaries; (2) for the exclusive purpose of providing benefits to participants and beneficiaries and paying reasonable expenses of administering the system ...." See Unif. Mgmt. Pub. Employee Ret. Sys. Act $\S 7$ (1997).

91 See RESTATEMENT (THIRD) OF TRUSTS $\S 227 \mathrm{cmt}$. c (2008) ("Prudent Investor Rule"); NLRB v. Amax Coal Co., Div, of Amax, 453 U.S. 322, 330 (1981) (noting that under common law and Restatement of Trusts, the "trustee bears an unwavering duty of complete loyalty to the beneficiary of the trust"). Although the decision to sue (and by what means) may not be an investment decision covered by the prudent investor rule, the trustee is also under a duty "to use reasonable care and skill to preserve the trust property." RESTATEMENT (SECOND) OF TRUSTS $\S$ 176 (1959); Knight v. Comm'r, 128 S. Ct. 782, 788 (2008). 
out and can point to no factor or special consideration that it was relying upon. Even then, the prospect of liability only becomes likely when some personal benefit is received. This is rare in the case of private pension funds, but possibly more common in union funds and public pension funds.

\section{What Will Be the Impact of Increased Opting Out on the Class Recovery?}

Suppose in a class action that settles for $\$ 2$ billion or more, 100 institutional investors opt out to sue in state court proceedings. By this point, defense counsel will presumably have anticipated some level of opt outs and attempted to address this issue in the settlement agreement. Traditionally, the settlement agreement would contain a provision under which defendants, at their option, could terminate the agreement if opt outs exceeded a specified level (say 10\%). But such a provision has long been an empty threat, which has seldom, if ever, been exercised. The problem with such a provision is that if the settlement agreement is terminated, the class action goes forward to trial. Few corporate defendants have the stomach for such an all or nothing gamble.

A more effective way to protect the corporation from opt outs would be a provision that reduced the settlement amount in respect of each opt out. But here, because the typical opt out recovers more than the typical class member, the corporate defendant would need to set the amount of the reduction at a level well above the amount that the opt out would have received under the class action if the defendant is to be held harmless. Thus, hypothetically, the class settlement amount might be reduced, for example, by five times the amount that the opt outs would have received under the settlement. Although such a tactic does hold the corporation harmless, there is now a significant cost to opting out that falls heavily on the smaller shareholders who remain behind within the class. Such a tactic will not deter opting out, but it will shift the cost of their gains to the remaining class members.

Of course, there are limits to the amount by which the class action can be reduced to reflect opt outs. If the reduction is disproportionate (and this is disclosed to the class), such a threatened reduction may backfire by forcing the remaining institutional investors who would not otherwise have opted out to do so. Also, to truly offset the amount that the opt outs will likely receive in individual actions, the reduction might have to be so disproportionate as to deplete and even exhaust the class action settlement. For example, if 100 institutional investors who collectively owned one third (or more) of the stock in the defendant corporation were to opt out, they might recover (based on the 
experience to date) $20 \%$ to $40 \%$ of their actual losses in individual actions, but today they would recover only $2 \%$ to $3 \%$ of their losses in the typical securities class action settlement. If the total market losses were $\$ 3$ billion and the opt outs represented one third (or $\$ 1$ billion) of these losses, they could expect recoveries of between $\$ 200$ million and $\$ 400$ million in individual actions. Yet, if the entire class today typically settles for between $2 \%$ and $3 \%$ of their losses, the class settlement fund would equal only $\$ 60$ to $\$ 90$ million, and the necessary reduction to hold the defendant harmless would exceed the total value of the settlement fund. Thus, the ability of defendants to protect themselves from opt outs through disproportionate reductions of the settlement fund seems limited. Although courts have yet to rule on this issue, a settlement agreement that contains a disproportionate reduction for opt outs (i.e., a reduction greater than their pro rata share of the class recovery) stands in danger of being rejected as unfair.

Nonetheless, because there is a possibility that opt outs will reduce the per share recovery to the remaining class members, the question must be faced: Should opt outs be restricted on fairness grounds? Should society be concerned that smaller investors might lose precisely to the extent that institutional investors did better? Here, three different lines of argument need to be considered:

First, principles of distributive justice may lead one to disfavor significant variations in the actual recovery that shareholders receive, but it is far from clear that such principles, or even cruder egalitarian biases, necessarily should lead one to oppose allowing institutions to opt out from the class. Even if such opt outs adversely affect the investors who remain in the class, these smaller investors in the class are still typically wealthy and diversified. In contrast, the beneficiaries of pension plans (and particularly public pension plans, which have been the most frequent opt outs) are characteristically poorer and dependent on their pensions for retirement income. Thus, if public policy is to be guided by a Rawlsian desire to favor the worst off, individual investors do not merit any preference over pensioners (or the beneficiaries of other institutional investors).

Second, even if opt outs injure the residual class members in the short-run, they may benefit them in the long-run. Over the long-run, increased opting out will place class counsel under increased competitive pressure to improve the class settlement. Faced with competition and a risk that a "cheap" settlement will produce a high rate of opt outs, class counsel must seek to reach a superior settlement in order to avoid the fee reduction that follows from a smaller class size caused by increased opt outs.

Third, opt outs should reduce the individual class member's recovery only when defendants negotiate disproportionate reductions to 
reflect the opt outs. Arguably, the simpler means of protecting the class is to limit the reduction of the class recovery to an amount proportionate to the opt outs' claims.

If one takes an optimistic perspective on contemporary developments, class counsel seems likely to be held accountable by active competition. To date, effective competition among the contenders for class counsel has largely been lacking. Although plaintiff's law firms certainly do compete to secure the lead plaintiff designation, their battles usually do little for shareholders because they do not compete in terms of price or performance. Not infrequently, their competition serves only to increase the campaign offers of some elected public officials. As a practical matter today, three plaintiffs' firms dominate the securities class action industry: Bernstein, Litowitz, Berger \& Grossmann; Coughlin, Stoia, Geller, Rudman \& Robbins; and Grant \& Eisenhofer. Other firms are active, but they seldom can command the institutional base necessary to secure lead plaintiff status in a large case. Still, with increased opting out, newer and smaller entrants can enter the field to represent opt outs. Symptomatically, counsel for many of the opt outs in the Qwest case was Entwistle \& Cappucci, a younger, smaller, and innovative firm, but not a firm in the top rank (by size or revenues) of the plaintiffs' bar.

A final question involves whether any policy measures could truly diminish the growing rate of opt outs. Defendants might prefer a mandatory class action from which opting out would not be permitted. But in Ortiz v. Fibreboard Corp.,$^{92}$ the Supreme Court made clear that Rule 23 of the Federal Rules of Civil Procedure does not countenance restrictions on opting out, and some federal courts have subsequently found the right to opt out from a class action for money damages to be of constitutional stature. ${ }^{93}$ If so, what alternative measures are feasible? Probably the most effective and feasible measure would be to give the JPML the power to consolidate state court individual actions with the federal class action for purposes of pretrial discovery. Modest as this step might sound, if the opt out were thus compelled to stay in the consolidated proceeding, the incentive to opt out would be reduced. Although the court handling the consolidated proceeding would be ultimately required to relinquish control of the individual actions (as the Supreme Court ruled in its Lexecon decision), ${ }^{94}$ "ultimately" can be a long time, and attempts to escape the transferee court have often been unsuccessful. ${ }^{95}$ 
The Class Action Fairness Act has already taken us well down the road towards federalizing tort law, ${ }^{96}$ and extending the power of the JPML so as to lock opt outs into federal court would only represent a marginal further step down this road. This essay is by no means recommending such a step, but, sooner or later, defendants will wake up to this possibility and begin lobbying.

\section{E. What Should Courts Do?}

If one believes that competition is desirable and that opt outs encourage it, several policy recommendations follow:

(1) Courts should not certify the class action (or, at least, permit the period for opt outs to expire) before the settlement's terms have been publicly disclosed. This would give those who are dissatisfied an opportunity to flee the class and pressure class counsel to satisfy its clients;

(2) Courts should reject proposed settlements that have disproportionate reductions for opt outs. Still, courts need not reject settlements that give the class the benefit of any higher payment made to an opt out. This would prevent discrimination in favor of the opt outs if the defendants are willing to take the risky step of binding their hands in this fashion.

(3) Where the opt out rate is significant, this fact is itself material to the shareholders and should be disclosed to them (with possibly an additional opt out period granted for them to reconsider).

These are modest proposals and largely consist of procedures that courts are already authorized to follow. In truth, the basic proposal made herein is to let the market work.

\section{CONCLUSION}

Accountability requires competition, and competition appears to be coming. How much competition results will depend on the still unknown breakpoint at which opt out claims become economically

cases are extremely fact specific, and no attempt will be made to describe them. Rather, the point is that the transferee court wants a global settlement and tends to see opt outs as an obstacle to that goal.

96 The Class Action Faimess Act of 2005, Pub. L. No. 109-2, 119 Stat. 4, 5, greatly restricts plaintiffs' ability to file a multi-state class action in state court in response to the perception that "rotten boroughs" existed in which plaintiffs could find friendly judges. See, e.g., Samuel Issacharoff, Settled Expectations in a World of Unsettled Law: Choice of Law After the Class Action Fairness Act, 106 COLUM. L. REV. 1839 (2006). No one yet has suggested that opt outs are also motivated by a similar desire to access "friendly" or partisan state court judges. 
viable. If, through coordination, investors with claims worth, say, $\$ 25$ million each (and maybe $\$ 100$ million in the aggregate) could afford to opt out and sue in a consolidated proceeding, then the class action will face large scale depletion. If the breakpoint is as high as $\$ 1$ billion, opt outs will have less impact, but will still encourage some increased competition as smaller firms enter the field by representing opt outs.

All this sounds like good news for investors-except for one final complication. Securities class actions face a circularity problem; in reality, investors are paid by investors, and often the result is a pocketshifting wealth transfer among the same diversified investors. ${ }^{97}$ Subtract from these wealth transfers the high transaction costs of litigation, and investors appear systematically to lose. That result does not change because actions are brought as individual actions rather than as class actions. Indeed, a higher rate of opt outs may even compound the injury, as the damages imposed on the corporation (and its shareholders) should grow.

Thus, even if agency costs are reduced, an optimal outcome is not necessarily reached. Increased exit is not then a panacea for all the problems of the securities class action, but no "magic bullet" can solve all these problems. Other things being equal, it is desirable to reduce agency costs (as greater competition should do). Other reforms may also be needed to shift liability, at least marginally, away from investors and onto responsible corporate officers and agents. Still, the need for such additional reforms does not supply an argument for preserving the current system in which attorneys, as agents, are only weakly accountable to their clients.

Ultimately, whether one likes it or not, competition is coming. 